\title{
An Evaluation of the Entrepreneurs' Perception of Business-Incubation Services in Kenya
}

\author{
Abel Kinoti Meru (Corresponding author) \\ The Catholic University of Eastern Africa \\ P.O. Box 62157-00200, Nairobi Kenya \\ Tel: +254-733-722-479Ｅ-mail: kinmru@yahoo.com \\ Miemie Struwig \\ School of Management Sciences \\ Nelson Mandela Metropolitan University \\ P.O. Box 77 000, Port-Elizabeth-6031, South Africa \\ Tel: +270-415-042-475Ｅ-mail: miemie.struwig@nmmu.ac.za
}

Received: July 18, 2011

Accepted: August 15, 2011 Published: November 21, 2011

doi:10.5430/ijba.v2n4p112

URL: http://dx.doi.org/10.5430/ ijba.v2n4p112

\begin{abstract}
Business incubators provide an important service network for new and fledgling Small and Medium Enterprises (SMEs) in Kenya. To ascertain the perception of the importance of business incubation process and how recipients perceive the service to be rendered, perceptions of 124 entrepreneurs are compared. The survey endeavored to cover all types of business-incubation programme in Kenya that target SMEs, but it was found that although close to twenty-five institutions operated some form of business incubation services or another, only twelve were confirmed as business incubators per se. The findings on the entrepreneurs' respondent, first from the descriptive statistics shows that the mean scores for the importance of services of business-incubation processes is higher than the rating of how actually the services were received. The hypothesis empirically tested using paired t-test indicates that a gap exist between how entrepreneurs' perceive business-incubation (services) process and what they actually receive. Based on the means of the two, they actually received less than anticipated. However, being a quantitative study the exact details of the real nature of business-incubation- services attached to the importance/ rendered services are not documented in the study. While the research provided new insights into business-incubation services in Kenya, numerous questions ring out in mind.
\end{abstract}

Keywords: Entrepreneurs, Business Incubation, Perceptions

\section{Introduction}

Most of the literature on incubator research focuses on the incubator facilities viewed in terms of multi-tenant buildings (Weinberg, Allen, \& Schermerhorn, 1991; Hurley, 2002) managed workspaces (Lalkaka, 1997); incubator buildings, speculative buildings and flex space (Hurley, 2002); greenhouse business facilities and business centres (Plosila \& Allen, 1985); or concentrates on business-incubator profiles (Hackett \& Dilts, 2004) but overlooks the underlying importance of incubation process. Several studies, though not comprehensive, have been used to explain the business- incubation phenomenon. Hackett and Dilts (Hackett \& Dilts, 2004) systematically reviewed twenty-six empirical, and nine non-empirical studies on research on business incubation. However, the study did not test any hypotheses or attempt to develop a theory, but provided rich descriptive data on five primary-research orientations that have so far guided research in the business-incubation industry. These include incubator development, incubator configuration, incubatee development, incubator-incubation impact and the theory of incubator-incubation.

Albert and Gaynor (Albert \& Gaynor, 2001) review key literature on business incubators and categorize the studies done into descriptive, prescriptive or evaluative research. Studies that describe incubators, mainly define, classify, identify features, map and model incubators, whereas, prescriptive studies focus on roles of incubators in economic development or features of successful incubator programmes, best practices and methodologies (Albert, Bernasconi, \& Gayno, 2004). Evaluative-centric studies, the focus of this study, concentrate on establishing metrics, quantifying incubator impacts, 
ranking the features of incubator programmes and assessing the effectiveness of incubation programmes (Albert et al, 2004). On the other hand, Autio and Klosften (Autio \& Klosften, 1998), based on a case study categorize incubation studies into two, the configuration-oriented and the process-oriented studies, the later focuses on the business-incubation process and relate mostly to active hands-on support for small and medium enterprises.

Business incubators are similar to other organizations and should be viewed as natural systems composed of an interrelated series of processes, that obtain supply of resources (input), a conversion process (throughput) and the production of an object or objects (output), explained as a cybernetic model (Silverman, 1970). An in-depth review of the literature suggests that there is no elaborate theory on business development, but there exists a multitude of inferences that seek to explain the phenomenon in terms of one form of entrepreneurial assistance and services offered as opposed to the process.

Erlewine and Gerl (Erlewine \& Gerl, 2004) observe that over years economic developers have for one reason or another used a 'three-legged tool' made of business attraction (financial and non-financial and quality of life incentives), business retention and entrepreneur- assistance strategies as strategic tools for economic development. The rationale for entrepreneur assistance strategies as further explained by Erlewine and Gerl (Erlewine \& Gerl, 2004) is to encourage entrepreneurial activity in disadvantaged areas by helping entrepreneurs overcome obstacles and to ultimately access essential resources necessary to create, grow and sustain new businesses.

Garnsey (Garnsey, 1998) observes that:

..incubation inside another organization during early resource access, mobilization and deployment is likely to enhance a firm's prospects for developing by protecting from early hazards.

Besides, it is worth noting that success of an incubated business relies on the extent to which incubation-programme staff understand and cater for the customers' needs especially in the handling of the business-development process (Molnar et al, 1997).

For the purpose of this study, a business incubator is defined as a nurturing environment for start-ups that provide business-support programmes and networking including physical infrastructure (in some cases) that enables businesses to develop within a controlled environment. According to Goldmark (Goldmark, 1996), business-development services include training, technology transfer, marketing assistance, business advice, mentoring and information aimed at helping small and micro-entrepreneurs improve the performance of their businesses.

The history of business incubators dates back to 1942 in the United States of America (Chinsomboon, 2000).The first documented incubator known as Batavia Industrial Center (BIC) located in Batavia, New York and was started in 1959. BIC which is still in operation, occupies a factory warehouse that was purchased by Charles Mancuso \& Sons Incorporated, after the Massey-Ferguson Company closed down, laying off 2,000 employees. As it was impossible to lease 850,000 square feet to one tenant, BIC took over the property and the renovated building built in 1882 (Lavrow \& Sample, 2000).

As one of the tenants in the building was a business that incubated chickens, Mancuso began to refer to his business complex as "the incubator", a name that spread very first in the neighbourhood. After the business of rearing chicken closed down, other businesses flourished owing to several innovations of the incubator concept such as shared services, flexible space at low cost and a nurturing environment (Hurley, 2002).

In South Africa, the concept of business incubation began in 1995 when the Small Business Development Corporation set-up the "hives of industry" (Lalkaka \& Abetti, 1999), which comprise a number of independent workstations that are put together to constitute a cluster of workshops. For example Ntsika, Khula and the Council for Scientific and Industrial Research have embarked on a wide range of incubator programmes (Mbewana, 2006). The history of business incubators in Kenya can be traced back to 1967 when the Industrial and Commercial Development Corporation (ICDC) established the Kenya Industrial Estate (KIE) as its subsidiary. Modelled along the concept of industrial estates, the first task of the Kenya Industrial Estate was to provide sheltered real estate services countrywide, along with the provision of financial and business development services, as a strategy geared toward local adaptation and industrialisation (Ikiara, 1988). Later, other types of business incubator sprang up that include; firstly, virtual incubators like Willpower Business Solutions Centre. Secondly, incubators without walls include some Non-Governmental Organizations (NGOs) and churches based institutions. Thirdly, incubators with walls include the International Finance Corporations Small and Medium Enterprises (SMEs) Solution Centre, the Kenya Kountry Business Incubator (Kekobi) and the Kenya Industrial Research and Development Institute (KIRDI) (Bwisa, 2005).

Remedios and Cornelius (Remedios \& Cornelius, 2003) observe that though the number of incubators is on the upward trend, it is still not clear whether incubators achieve their goals or their exact impact on the tenant. Further gaps exist in 
knowledge on how organizations develop in the protected incubated environment and the impact of diverse stakeholders. Research in the area of business incubation has thus not gone beyond investigating how many jobs are generated and how many businesses have graduated from incubators. These very broad-based evaluators fail to provide a detailed picture of the impact of incubator programmes on business development. This is a critical drawback in incubation literature (Remedios \& Cornelius, 2003).

Despite these developments, Voisey, Gornall, Jones and Thomas (Voisey, Gornall, Jones, \& Thomas, 2006) note that there is little evidence showing how incubating businesses thrive in the incubator and incubatees experiences, despite the fact that much entrepreneurial literature on new business development has been written. From the brief background, it is clear that business incubators play an important potential role in economic development. However, there is still little, if any research, to ascertain the perceived importance of the business-incubation process and actual services received by the incubatees/ graduate firms.

Hannon (Hannon, 2005) notes that although much as been written about incubators, very little if any has been reported on the incubation process. Thus, there is a research gap between studies on business incubators and research on business-incubation services and also on how the entrepreneurs' perceive the importance businesses-incubation services and how the services are rendered.

\section{Problem Investigated}

The United Nations Economic Commission of Europe (United Nations Economic Commission of Europe, 2002) explains that business incubation also means the development of a supportive and stimulating environment for entrepreneurship. Scholars of the business incubation concept have agreed that small-business incubation is a dynamic process where start-up businesses are nurtured to enable them survive and grow during difficulty times (Remedios \& Cornelius, 2003). Hackett and Dilts (Hackett \& Dilts, 2004) observe that just as a business is not merely an office in a building, a business incubator should also be understood from the view point of myriads of networks that operate within and outside of it, which is what business incubation is per se.

Hannon (Hannon, 2003) underpins the necessity of understanding the pillars that make up the incubation process, mainly the transfers of ideas, knowledge or research to the marketplace. Hannon (Hannon, 2005) further, note that new opportunities to explore methods for facilitating incubation processes concerns numerous critical aspects of business incubation, such as, governance and control, management and leadership, professionalism and personal development, client monitoring and tracking, impact assessment and evaluation.

Autio and Klosften (Autio \& Klosften, 1998) assert that all small and medium enterprises assistance arrangements are localized in terms of local or regional industries and the local business environmental setting differ in terms of regulatory framework, financial and institutional requirements. Basically, the type of service offered could be real estate, basic office services, advisory and support services, training and contact building. The financial models revolve around rental and external services, subsidies, sponsorships, and deferred revenue, for example, royalties. Finally, the context may be rural or urban, and range from mixed use incubators to high-tech, corporate incubators and special-interest incubators. For the purpose of this research, the business-incubation process encompasses the provision of the following services; training, business support, financial support, technology support, facilities and infrastructure, networking and mentoring, and after-care services.

U.S. Department of Commerce, Technology Administration (Technology Administration, 2003) report based on a study of 17 "best in class" technology business incubators in United States of America (USA) using a qualitative research design found out that there is a predictive relationship between incubators business assistance programmes and the secondary business outcomes of an incubated enterprise. Tornatzky, Sherman, and Adkins's (Tornatzky, Sherman, \& Adkins, 2003) research on technology business incubators in the in USA using incubator managers as the exclusive respondents, yielded no strong statistical relationships based on multiple regression analysis between incubator business-assistance practices and primary outcomes (for example, sales and revenue growth). However, the study noted that individual skills of the incubator manager were great predictors of performance rather than whether the incubator provided mentoring relationships.

Remedios and Cornelius (Remedios \& Cornelius, 2003) observe that research on performance measurement emerged from two dimensions, namely, organization theory, focusing on goal-based, systems (multiple generic performance aspect) and multiple- constituency approaches (agenda for stakeholders). The second dimension, strategic management, combined the three-developed measures based on financial performance (market share, sales, operating cost) and organization effectiveness, measured through product quality and market share. Though these measures yield sense if applied in corporate environments, Remedios and Cornelius (Remedios \& Cornelius, 2003) further acknowledge that 
since it may be difficult to collect financial data from small businesses, operational measures can be used to assess performance of start-ups within a business incubation environment.

For instance, Lofsten and Lindelof (Lofsten \& Lindelof, 2001) using a longitudinal study compared performance of science park tenants to similar tenants located outside and found a positive impact of business's growth as measured by sales and jobs created. However, the approach itself suffers from methods of identifying comparison groups.

\subsection{Research Objective}

The primary objective of this research is to assess the entrepreneurs' perception of business-incubation services in Kenya. In order to achieve the primary objective, the research study sought to answer the following questions; are there any discrepancies "gaps" between the entrepreneurs' perceptions of the importance of the business-incubation services (training, business support, financial, and technology support, facilities and infrastructure, networking and mentoring, and after-care services) and how they perceive the services to be rendered

\subsection{Research Hypothesis}

Based on the research questions raised, the following hypothesis guided the research in the assessment of the perception of the business incubation services in Kenya.

'There is a significant relationship between the entrepreneurs' perceptions of the importance of the business- incubation process (training, business support, financial, and technological support, facilities and infrastructure, networking and mentoring, and after care services) with how they perceive the services to be rendered'.

\section{Methodology and Sample}

The study utilizes quantitative research designs, based on a cross-sectional research design to evaluate the entrepreneurs' perception of the business-incubation services in Kenya. The population of study encompassed all types of business-incubation programme in Kenya that target SMEs. The sample for the survey was drawn from a list of incubators obtained from Business Incubation Association of Kenya (BIAK).

The BIAK list showed that close to twenty-five institutions in Kenya operated some form of business incubation services or another, but only twelve could be confirmed as business incubators per se. The list of twelve business incubators was used to draw a random sample comprising of two hundred entrepreneur businesses/incubatees. The sample was representative of the main players in the business-incubation industry that comprised of government institutions, private providers and non-governmental organizations.

However, the sample size itself was influenced by many factors such as the basic characteristics of the population, credibility, time and financial constraints, non-response factor and statistical precision. A total of 124 incubating businesses/entrepreneurs responses were received, representing a response rate of $62 \%$.

Prior to the data-collection exercise, a research permit no. MOHEST 13/001/38C 323, to carry out the research in the Republic of Kenya was obtained from the Ministry of Higher Education Science and Technology.

\subsection{Research Instruments}

The structured questionnaires used in the study were based on information obtained during the literature study (secondary research). Specific measures were also taken to ensure consistency and reliability of the questionnaire. The survey questionnaire for the incubating business/entrepreneur was made up of six sections, namely, background information, characteristics of the entrepreneur, incubation process, business-environmental factors, overall performance of the business and biographical information.

These business-incubation services were measured by a total of twenty-seven items, based on two sets of Likert scales, where the first sought the respondents' opinion on how important the factors were ranging from very important to not applicable. In the second Likert scale, respondents rated the services received from the incubator as well above average to poor. Each of the variables was measured according to; training (training regularly, entrepreneurial development and management training), business support (start-up business creation services, back-up office support, legal services, back-up office support, business advice regularly, marketing and sales services, counselling services); financial support (subsidized services, access to finance, bookkeeping services, equity participation) and technology support (internet services, technology transfer, patent and copyright protection, production/operations equipment).

Facilitates and infrastructure were measured by working space, office furniture and equipment, physical safety and security, and enhanced visibility. Networking and mentoring used industry linkages, business collaboration within the incubator, international shows and exhibitions and mentorship programmes. After-care was measured by post-incubation services. 
In addition, respondents were asked to rate how important the business-incubation process had been to the development of their businesses. Finally, their views were sought on the number of employees/units of product/services held then and at the time of joining the incubator. The same was required with gross sales turnover per month, number of copyrights, patents and trade marks.

The respondents were further asked whether their ability to take new initiatives, mobilise resources, manage business, take risks, perceive opportunity, and survive in business had increased, decreased or remained constant as a result of the incubation programme.

Based on responses from sets of statements that describe the interdependencies or inter-relationships among the group, data obtained was subjected to paired t-test. Lee et al (Lee et al, 2004) used two survey instruments one for incubator managers and another for entrepreneur clients and graduate businesses to measure characteristics and factors that impact on effective operations of university business incubators in the United States and Korea. They used t-test to compare the results between the two countries.

Hsu et al (Hsu et al, 2003) used regression analysis to explore the interaction between incubators and industrial clusters. Therefore, the data computational methods adopted for the research have previously yielded statistically significant results. This re-affirms the degree of confidence used for this research.

\subsection{Testing of the Questionnaire}

Before the pre-test was done, two senior university researchers were requested to review the questionnaires in order to determine face validity. All their comments were noted and incorporated into the questionnaires. As a rule in sample surveys, a pre-test was carried out in selected incubators mainly to test the applicability of the questionnaires, among eight incubating businesses. The pre-test results were relied on in finalizing the questionnaire. In this way, content validity was ensured.

To ensure the reliability of the information, methodological data triangulation was used. Struwig and Stead (Struwig \& Stead, 2001) explain that reliability is the extent to which "test scores are accurate, consistent and stable”. Data was collected from different sources, including the incubator manager and from the entrepreneur/incubating businesses (tenants and graduates) in the study of business incubation and business development.

The validity of a measuring instrument's scores refers to the extent to which the instrument measures what it is intended to measure. In addition to face and content validity the researcher also pursued construct validity of the measuring instrument. The process of construct validation includes defining the constructs and hypothesizing their relationships to other variables developed. The researcher further utilized exploratory factor analysis, to ascertain the interdependency among hypothesized variables.

Cronbach's alpha is very useful for interval-level measurement involving multi-item scales, especially to check homogeneity of internal consistency of underlying constructs (Cooper \& Schindler, 2006) based on inter-item correlation means, in order to measure the reliability of the instruments. The Cronbach's alpha reliability analysis was done for the entrepreneur/incubating businesses questionnaire and found to be good (Cronbach alpha $>0$. 7).

Nachmias and Nachmias (Nachmias \& Nachmias, 1992) observe that:

The reliability measures varies on a scale of 0 to 1 , having the former value when the measurement involves nothing but error and reaching 1 when there is no variable error at the measurement

\subsection{Data Collection}

Four research assistants were hired and trained on how to administer the research instruments for half a day. The fieldwork was undertaken during the months of July and August 2008 from incubator managers and the entrepreneurs of client businesses (tenant and graduate businesses). This was done in four phases. In the first phase, letters were written and forwarded to the Executive Directors informing them of the survey, their role and requesting permission to solicit information from incubating businesses. The second phase was initiated with phone calls to the incubator managers briefing them on the survey. In the third phase, questionnaire(s) for incubating businesses/entrepreneurs were dropped as discussed with the managers telephonically and a briefing session was held.

The purpose of the meeting was to assist in drawing up a random list of incubating businesses that were to participate in the study. Afterwards the questionnaires were distributed with strict instructions that only the owners were to complete the questionnaires and when completed, they were also requested to forward the completed questionnaires to the incubator managers. Where questionnaires were administered outside the incubators from the Nairobi office, the internal-mailing system was used. However, the method was deployed to only one incubator that had a presence in several parts of the country. 
Whereas all the business incubators included in the sample were from the Nairobi province, efforts were made to reach remote incubating businesses/entrepreneurs, however, the response outside Nairobi was dismal, since 81.5\% ( $\mathrm{n}=101)$ of the respondent incubating businesses/entrepreneurs came from Nairobi province, Central province had $4.0 \%(n=5)$. Businesses from Maragua, Muranga and Thika towns in central province, and from Rift Valley, Eastern and Western provinces, were two each.

In the final phase, several phones calls were made to arrange for the collection of the questionnaires, to ensure a good response rate. The questionnaires, once gathered, were edited, coded, and processed using SPSS statistical package.

\section{Empirical Results}

\subsection{Descriptive Statistics}

The majority of the respondent entrepreneurs, $69.4 \%(n=86)$ were males, while females constituted $30.6 \%(n=38)$ of the sample size, with an age range of that varied between 22 to 62 years at mean age of 32.7 years. $61.3 \%(n=76)$ of them held bachelor degrees and above, with approximately $64.5 \%(n=80)$ of them with formal education that entrepreneurial subjects. $24.2 \%(n=30)$ of the entrepreneurs owned the business, $55.6 \%(n=69)$ were owners cum active managers, while $11.3 \%(n=14)$ employed managers.

The number of incubator management staff involved in business development services and back-up office support ranged from one to four persons or $62.5 \%(n=5)$ of the incubators, the staff involved in information technology/internet services as it also applies to accounting and finance ranged from one to two in $50.0 \%(n=4)$ of the incubators, one to two persons, that is $37.5 \%(n=3)$, were engaged for marketing incubator-services and another one to two or $12.5 \%(n=1)$, were engaged in legal services.

It is discernable that $87.5 \%(n=7)$ of the incubators had incubated ICT-based businesses ranging from 1-20 businesses. Service-sector businesses ranged from one to fifteen businesses in $75 \%(n=6)$ of the incubators (some of which were in ICT), while others were in retail and manufacturing sector. 78.2\% ( $\mathrm{n}=97)$ sampled entrepreneurs, indicated that they had started their businesses between year 2004 and 2008; 12.1\% (n=15) had started between 1999 and 2003; $5.7 \%$ ( $\mathrm{n=7}$ ) between year 1994-1998 and 2.97\% ( $\mathrm{n}=2$ ) before 1993 and the oldest entrant joined the incubator in 1989. Most of the entrepreneur respondents, $47.6 \%(n=59)$ were in the service industry, $29.0 \%(n=36)$ were ICT based businesses, $13.7 \%$ $(n=17)$ were in the retailing business, while $5.6 \%(n=7)$ were in the manufacturing industry.

Most of the incubating businesses or $53.2 \%(n=66)$ had started from outside the incubator; $36.3 \%$ ( $n=45)$ had begun as start-ups in the incubator. Only $13(10.5 \%)$ of the incubating businesses had other business located outside of the incubator, whereas the majority or $51.6 \%(n=64)$ of the incubating businesses had no other businesses elsewhere. Further analysis of the findings, showed that at the time of the field study, $79 \%(n=98)$ of the businesses were residing in the incubator, $7.3 \%(n=9)$ had graduated from the incubator, $4.0 \%(n=5)$ were anchor tenants; another $4.0 \%(n=5)$ were unsuccessful former tenants while $1.6 \%(\mathrm{n}=2)$ belonged to other categories.

On the question of ownership, 33.9\% $(n=42)$ were private companies; 31.5\% $(n=39)$ were partnerships; $27.4 \%(n=34)$ were sole proprietorship; $4.0 \%(n=5)$ were public-limited businesses and two were owned by non-governmental organizations.

Incubating businesses employing less than three personnel constituted 62.9\% ( $\mathrm{n}=78) ; 25.8 \%(\mathrm{n}=32)$ employed between four and nine personnel, 7.3\% ( $n=9)$ employed between ten and 19 personnel; 2.4\% ( $n=3)$ had between 20 and 49 employees and only one had employed more than 50 personnel.

Results from the descriptive statistics as shown in Table 1 shows that the mean scores for the importance of services of business-incubation process is higher than rating of how actually these services were received. This implies that service delivery fell short of the entrepreneurs' perceptions.

From Table 1, it is evident that the highest entrepreneurs' mean rating on the importance of services that an incubator can provide, is for training, followed by facilities and infrastructure, then business support and networking and mentoring. In terms of how entrepreneurs' rated the services they received, facilities and infrastructure was rated highest followed by training, then technology support and then business support.

\subsection{Testing of Hypothesis}

The research sought to find out whether there is any significant difference between the importance entrepreneurs/incubating businesses attach to business-incubation services that an incubator can provide and the rating they gave for the services received. Though the two questions were independent, the items on the statements were the same, one question sought responses on the importance and the other, the rating of these services in order to test the hypothesis that: 
There is a significant relationship between the entrepreneurs' perceptions of the importance of the business-incubation process (training, business support, financial, and technological support, facilities and infrastructure, networking and mentoring, and after-care services) with how they perceive the services to be rendered at the incubator.

Hair, Bush and Ortinau (Hair, Bush \& Ortinau, 2006) observe that when testing for differences in related samples, the researcher must consider using paired-samples t-test. Hence, paired t-test is ideal when two or more group of responses originate from the same sample population, and was found appropriate for testing of the hypothesis as presented in Table 2.

The essence of Table 2 was to determine whether the mean rating of the importance of services an incubator can provide differed significantly with the rating of how the same services were perceived to have been received, since the same respondents provided the answers.

The p-values for all the comparisons were statistically significant at 0.000 levels.

Therefore, the hypothesis was accepted that:

significant relationships exist between the mean ratings of entrepreneurs' perceptions of the importance of the businessincubation process (training, business support, financial, and technological support facilities and infrastructure, networking and mentoring, and after-care services) with how they perceive the services to be rendered.

Thus, a gap exists between how entrepreneurs perceive the business incubation services and what they actually received. Based on the means of the two, they actually received less than anticipated.

\section{Conclusions}

Firstly, although entrepreneurs attach great importance to the business-incubation services, actual services received fall short of their expectations. From the analysis, therefore, incubating businesses/entrepreneurs received less business incubation services than they had perceived. Disparities, in service delivered may be the result of most incubators being driven by the need for profit and thus neglecting to focus on excellent service delivery, and the fact that out of the twelve incubators contacted, only two were owned by the Kenyan Government

\subsection{Implications of the Study}

The Information for Development Programme (2006) workshop report stresses that business development services operate on a microeconomic level that may have an impact on local communities. However, to be sustainable and scalable, they must be accompanied by ideal macroeconomic policies. As their impacts are often minor and incremental, it takes time to show tangible results.

To promote the business incubation process in Kenya, the government should spearhead the incubation process, first by enacting an incubation policy, to guide the stakeholders on incubator goals, roles and outcomes. Secondly, this policy should also address the financing aspect as most incubated activities are funded by governments in other countries. Thirdly, clear guidelines for provision of business-incubation services should be developed and implemented. Since $49.2 \%$ of incubatees hold a minimum of a bachelor's degree, such a highly- competent and trained cadre could hold the future of Kenya if all these talents are nurtured and put into productive and value-adding high-technology sectors.

Future research, should strive to evaluate entrepreneurs' perceptions of business-incubation services in Kenya based on longitudinal studies, including an in-depth analysis of the effect of networking on growth of the business. Since sample of this research does not include many businesses in the rural areas of Kenya and the study mainly focussed on incubators in the Nairobi area. It is expected that the degree of development, may be even worse in the rural areas and the degree of service delivery, of which requires diverse translations into numerous local languages, may be too complicated, unless area specific area studies are conducted.

\section{References}

Adkins, D. (2002). A Brief History of Business Incubation in the United States. Athens: OH. National Business Incubation Association.

Albert, P \& Gaynor, L. (2001). Incubators-Growing up, Moving out: A Review of the Literature. Chair of High Tech Entrepreneurs. Ceram Sophia Antipolis. [Online] Available: http://www.ceram.fr. on September 8, 2007.

Albert, P., Bernasconi, M. \& Gaynor, L. (2004). Incubation in Evolution: Strategies \& Lessons Learned in Four Countries, France, Germany, United Kingdom \& United States of America. Athens, OH: National Business Incubation Association. 
Autio, E. \& Klofsten, M. (1998). A Comparative Study of Two European Business Incubators. Journal of Small Business Management, 36 (1): 30-43.

Boyd, H.W., Westfall, R. \& Stasch, S.F. (1990). Marketing Research: Test \& Cases. New Delhi: Richard D. Irwin, Inc.

Bwisa, H. (2005). The Kenyan Experience in Business Incubators. A Paper presented at Jomo Kenyatta University of Agriculture \& Technology Workshop, 12th-14th, May 2005,Garden Hotel,Machakos,Kenya.

Chinsomboon, O.M. (2000). Incubators in the New Economy. Sloan School of Management, Massachusetts Institute of Technology. (Unpublished Master of Business Administration Thesis).

Cooper, D.R. \& Schindler, P.S. (2006). Business Research Methods. (8th ed). New York: McGraw Hill/Irwin.

Erlewine, M. \& Gerl, E. (2004). A Comprehensive Guide to Business Incubation. Athens, OH: National Business Incubation Association.

Garnsey, E. (1998). A Theory of the Early Growth of the Firm. Industrial \& Corporate Change, 7(3), 523-555.

Goldmark, L. (1996). Business Development Services: A Framework for Analysis. Micro-Enterprises Unit, Inter-American Development Bank, Washington, DC. Working Paper No. MIC-101.

Hackett, M. \& Dilts, D.M. (2004). A Systematic Review of Business Incubation Research. The Journal of Technology Transfer, 29 (1), 55-82.http://dx.doi.org/10.1023/B:JOTT.0000011181.11952.0f

Hair, J.F., Bush, R.P. \& Ortinau, D.J. (2006). Marketing Research: Within a Changing Environment. (3rd ed). New York: McGraw-Hill/Irwin.

Hannon, P. (2003). A Conceptual Development Framework for Management \& Leadership Learning in the UK incubator Sector. Education \& Training, 45 (8/9), 449-460.http://dx.doi.org/10.1108/00400910310508847

Hannon, P. (2005). Incubation Policy \& Practice: Building Practitioner \& Professional Capability. Journal of Small Business \& Enterprise Development, 12 (1): 57-75.http://dx.doi.org/10.1108/14626000510579644

Hsu, P.H., Shyu, J.Z., Yu, H.C., Yuo, C.C., \& Lo, T.H. (2003). Exploring the Interaction between Incubators \& the Industrial Clusters: The Case of the ITRI Incubator in Taiwan. Research \& Development Management, 33 (1), 79-90.

Hurley, K. (2002). The First Incubator Business: Incubator Building. Economic Development Journal, Spring: 53-56.

Ikiara, K. (1988). The Role of Government Institutions in Kenya?s Industrialization in Kenya. In Coughlin, P. \& Ikiara, G. K. Industrialization in Kenya: In Search of A Strategy. Nairobi: East African Educational Publishers Ltd.

Information for Development Programme. (2006). Promoting Innovation \& Entrepreneurship in Africa, Africa Regional Workshop: InfoDev Incubator Initiative, 3rd-5th May, Accra, Ghana.

Lalkaka, R. \& Abetti, P. (1999). Business Incubation \& Enterprise Support Systems in Restructuring Countries. Creativity \& Innovation Management, 8 (3): 197-209. http://dx.doi.org/10.1111/1467-8691.00137

Lalkaka, R. (1997). Lessons from International Experience for the Promotion of Business Incubation Systems in Emerging Economies. Vienna: UNIDO.

Lavrow, M. \& Sample, S. 2000. Business Incubation: Trend or Fad? Incubating the Start-up Company to the Venture Capital Stage: Theory \& Practise. University of Ottawa. (Unpublished Master of Business Administration Thesis).

Lee, S.S. \& Osteryoung, S. (2004). A Comparison of Critical Success Factors for Effective Operations of University Business Incubators in the United States \& Korea. Journal of Small Business Management, 42 (4), 418-426.http://dx.doi.org/10.1111/j.1540-627X.2004.00120.x

Lofsten, H. \& Lindelof, P. (2001). Science Parks in Sweden-Industrial Renewal \& Development. Research \& Development Management, 31 (3), 309-322.

Mbewana, P.N. (2006). The Key Success Factors for Business Incubation in South Africa: The Godisa Case Study. University of Pretoria. (Unpublished Master of Science Dissertation).

Molnar, L.A., Grimes, D.R., Edelstein, J. Pietro, R.D., Sherman, H., Adkins, D. \& Tornatzky, L. (1997). Business Incubation Works: The Results of the Impact of Incubator Investment Study. Athens: OH: National Business Incubation Association

Nachmias, C.F. \& Nachmias, D. (1992). Research Methods in the Social Sciences. (4th ed). London: Edward Arnold. 
Plosila, W. \& Allen, D.N. (1985). Small Business Incubators \& Public Policy: Implications for States \& Local Development Strategies. Policy Studies 729-734.http://dx.doi.org/10.1111/j.1541-0072.1985.tb01612.x

Remedios, R.K. B. \& Cornelius B. (2003). Cracks in the Egg: Improving Performance in Business Incubation Research. A paper for the Small Enterprise Association of Australia \& New Zeal\&, 16th Annual Conference, 28th September to 1st October, University of Ballarat. Ballarat.

Silverman, D. (1970). The Theory of Organizations: A Sociological Framework. London: Heinemann Educational Books Limited.

Struwig, F.W. \& Stead, G. D. (2001). Planning, Designing \& Reporting Research. Cape Town: Pearson Education South Africa.

Tornatzky, L., Sherman, H., \& Adkins, D. (2003). Incubating Technology Businesses: A National Benchmarking Study. Athens, OH: National Business Incubation Association.

U.S. Department of Commerce, Technology Administration. (2003). Report on a National Benchmarking Analysis of Technology Business Incubator Performance \& Practices. Athens, OH: National Business Incubation Association.

United Nations Economic Commission for Europe (UN/ECE). (2002). Best Practises in Business Incubation in Countries in Transition: Prepared for the European Forum on Business Incubation: Accelerating, Connecting, Enabling. Paris, Cite? des Sciences et de l?endustrie, 21-22, March 2002.

Voisey, P., Gornall, L., Jones, P. \& Thomas, B. (2006). The Measurement of Success in a Business Incubation Project. Journal of Small Business \& $\quad$ Enterprise $\quad$ Development, 13 (3),454-468.http://dx.doi.org/10.1108/14626000610680307

Weinberg, M. L., Allen, D. N. \& Schermerhorn, Jr.J.R. (1991).Interorganizaton Challenges in the Design \& Management of Business Incubators. Policy Studies Review, 149-160.http://dx.doi.org/10.1111/j.1541-1338.1991.tb00103.x

Table 1. Comparative Mean difference of importance and actual delivery of services by the entrepreneurs and managers combined.

\begin{tabular}{|c|c|c|c|}
\hline \multirow{2}{*}{$\begin{array}{c}\text { Business } \\
\text { incubation Services }\end{array}$} & $\begin{array}{c}\text { Importance of services an incubator } \\
\text { can provide } \\
\text { (Means) }\end{array}$ & $\begin{array}{c}\text { Rating of services received from an } \\
\text { incubator } \\
\text { (Means) }\end{array}$ & $\begin{array}{c}\text { Mean } \\
\text { difference }\end{array}$ \\
\hline Training & 4.22 & 2.96 & 1.26 \\
\hline $\begin{array}{c}\text { Facilities and } \\
\text { infrastructure }\end{array}$ & 4.07 & 3.35 & 0.72 \\
\hline Business support & 3.92 & 2.80 & 1.12 \\
\hline $\begin{array}{c}\text { Networking and } \\
\text { mentoring }\end{array}$ & 3.90 & 2.72 & 1.18 \\
\hline Technology support & 3.82 & 2.82 & 1.00 \\
\hline Financial support & 3.77 & 2.52 & 1.25 \\
\hline After-care services & 3.69 & 2.51 & 1.18 \\
\hline
\end{tabular}


Table 2. Paired t-test sample statistics on the importance of services that an incubator can provide and rating of business incubation services received from an incubator by entrepreneur respondents.

\begin{tabular}{|c|c|c|c|c|c|}
\hline Business incubation services & $\begin{array}{c}\text { Important of services an } \\
\text { incubator can provide } \\
\text { (Means) }\end{array}$ & $\begin{array}{l}\text { Rating of services received } \\
\text { from an incubator } \\
\text { (Means) }\end{array}$ & $\begin{array}{c}\text { Means } \\
\text { difference }\end{array}$ & t-value & $\begin{array}{l}\text { Significance } \\
\text { (2 -tailed) } \\
\text { (p-value) } \\
\end{array}$ \\
\hline Training regularly & 4.14 & 2.97 & 1.17 & 10.117 & $.000 *$ \\
\hline Entrepreneurial development & 4.29 & 3.01 & 1.28 & 12.241 & $.000 *$ \\
\hline Management training & 4.24 & 2.90 & 1.34 & 11.277 & $.000^{*}$ \\
\hline $\begin{array}{c}\text { Start-up business creation } \\
\text { services }\end{array}$ & 3.93 & 3.00 & 0.93 & 7.155 & $.000 *$ \\
\hline Back-up office support & 3.98 & 3.03 & 0.84 & 6.245 & $.000 *$ \\
\hline Legal services & 3.57 & 2.35 & 1.22 & 8.596 & $.000 *$ \\
\hline Business advice regularly & 4.14 & 2.83 & 1.31 & 12.193 & $.000 *$ \\
\hline Marketing and sales services & 4.23 & 3.00 & 1.23 & 10.376 & $.000 *$ \\
\hline Working space & 4.49 & 3.83 & 0.65 & 6.795 & $.000 *$ \\
\hline $\begin{array}{l}\text { Office furniture and } \\
\text { equipment }\end{array}$ & 4.01 & 3.46 & 0.55 & 4.966 & $.000 *$ \\
\hline Physical safety and security & 4.03 & 3.47 & 0.56 & 4.790 & $.000 *$ \\
\hline Enhanced visibility & 3.96 & 3.26 & 0.71 & 5.819 & $.000 *$ \\
\hline Industry linkages & 3.96 & 2.85 & 1.11 & 8.420 & $.000 *$ \\
\hline $\begin{array}{l}\text { Business collaboration within } \\
\text { the incubator }\end{array}$ & 3.99 & 3.07 & 0.92 & 7.346 & $.000 *$ \\
\hline $\begin{array}{c}\text { International shows and } \\
\text { exhibitions }\end{array}$ & 3.76 & 2.23 & 1.54 & 10.087 & $.000 *$ \\
\hline Subsidized services & 3.89 & 2.88 & 1.01 & 6.809 & $.000 *$ \\
\hline Access to finance & 3.97 & 2.21 & 1.76 & 11.746 & $.000 *$ \\
\hline Bookkeeping services & 3.65 & 2.39 & 1.25 & 8.769 & $.000 *$ \\
\hline Equity participation & 3.57 & 2.55 & 1.03 & 6.550 & $.000 *$ \\
\hline Internet services & 3.99 & 3.27 & 0.72 & 5.175 & $.000 *$ \\
\hline Technology transfer & 3.84 & 2.96 & 0.87 & 6.724 & $.000 *$ \\
\hline $\begin{array}{c}\text { Patent and copyright } \\
\text { protection } \\
\end{array}$ & 3.56 & 2.26 & 1.30 & 9.311 & $.000 *$ \\
\hline $\begin{array}{c}\text { Production/operations } \\
\text { equipment } \\
\end{array}$ & 3.88 & 2.79 & 1.08 & 7.645 & $.000 *$ \\
\hline Expansion facilities & 3.86 & 2.73 & 1.13 & 8.900 & $.000 *$ \\
\hline $\begin{array}{c}\text { Post-incubation business } \\
\text { services } \\
\end{array}$ & 3.69 & 2.51 & 1.18 & 8.730 & $.000 *$ \\
\hline Mentorship programme & 3.88 & 2.71 & 1.17 & 9.950 & $.000 *$ \\
\hline Counselling services & 3.65 & 2.58 & 1.08 & 8.457 & $.000 *$ \\
\hline
\end{tabular}

* Significant at $\mathrm{p}<0.05$ 